\title{
REVISTA DE NUTRIÇÃO
}

versão impressa ISSN 1415-5273

Rev. Nutr. v.25 n.6 Campinas nov./dez. 2012

ERRATA

Página 753 - Afiliação Institucional

Onde se lê:

Jane Delane Reis PIMENTEL-SOUZA ${ }^{1}$

Danilo Santos SOUZA ${ }^{1}$

Nayjara Carvalho GUALBERTO'

Suyare Araújo RAMALHO ${ }^{1}$

Jane de Jesus da Silveira MOREIRA ${ }^{2}$

Narendra NARAIN ${ }^{3}$

REVISTA DE NUTRIÇÃO

versão impressa ISSN 1415-5273

Rev. Nutr. v.25 n.6 Campinas nov./dez. 2012

ERRATA

Página 753 - Afiliação Institucional

Leia-se:

Jane Delane Reis PIMENTEL-SOUZA ${ }^{1}$

Danilo Santos SOUZA ${ }^{1}$

Nayjara Carvalho GUALBERTO'

Suyare Araújo RAMALHO ${ }^{1}$

Jane de Jesus da Silveira MOREIRA ${ }^{1}$

Narendra NARAIN ${ }^{1}$ 